\title{
The EU societal awareness of landscape indicator: a review of its meaning, utility and performance across different scales
}

Article

Accepted Version

Jones, P. J., Anderson, E., Capitani, C., Carvalho Ribeiro, S., Griffiths, G. H., Loupa-Ramos, I., Madeira, L., Mortimer, S. R., Paracchini, M. L., Pinto Correia, T., Schmidt, A. M., Simoncini, R. and Wascher, D. M. (2015) The EU societal awareness of landscape indicator: a review of its meaning, utility and performance across different scales. Land Use Policy, 53. pp. 112-122. ISSN 0264-8377 doi:

https://doi.org/10.1016/j.landusepol.2015.01.038 Available at https://centaur.reading.ac.uk/39486/

It is advisable to refer to the publisher's version if you intend to cite from the work. See Guidance on citing.

To link to this article DOI: http://dx.doi.org/10.1016/j.landusepol.2015.01.038

Publisher: Elsevier

All outputs in CentAUR are protected by Intellectual Property Rights law, including copyright law. Copyright and IPR is retained by the creators or other copyright holders. Terms and conditions for use of this material are defined in the End User Agreement. 


\section{www.reading.ac.uk/centaur}

\section{CentAUR}

Central Archive at the University of Reading

Reading's research outputs online 
1 Title: The EU societal awareness of landscape indicator: a review of its meaning, utility and 2 performance across different scales.

3 Authors: Jones, P. J. ${ }^{1}$, Andersen, E. ${ }^{2}$, Capitani, C. ${ }^{3}$, Carvalho Ribeiro, S. ${ }^{4}$, Griffiths, G. H. ${ }^{1}$, Loupa4 Ramos, I. ${ }^{5}$, Madeira, L. , Mortimer, S. R. ${ }^{1}$, Paracchini, M.L. ${ }^{3}$, Pinto Correia, T. ${ }^{4}$, Schmidt, A. M. ${ }^{6}$, 5 Simoncini, R. ${ }^{7}$ and Wascher, D. M. ${ }^{6}$

6

$7{ }^{1}$ School of Agriculture, Policy and Development, PO Box 237, Earley Gate, University of Reading,

8 Reading, RG6 6AR, UK (Corresponding author, p.j.jones@reading.ac.uk; Tel. +44 (0)118 3788186)

$9{ }^{2}$ University of Copenhagen, Rolighedsvej 23, 1958 Frederiksberg C, Denmark (eran@ign.ku.dk)

$10{ }^{3}$ Institute for Environment and Sustainability, Joint Research Centre, Via E. Fermi 2749 - TP 261,

1121020 Ispra (VA), Italy (luisa.paracchini@irc.ec.europe.eu)

$12{ }^{4}$ ICAAM - Instituto de Ciências Agrárias e Ambientais Mediterrânicas, University of Evora, , Apt.94, 7002-554 Évora, Portugal (sribeiro@uevora.pt, mtpc@uevora.pt,)

$14{ }^{5}$ CESUR, Instituto Superior Técnico, University of Lisbon, Av. Rovisco Pais, 1049-001 Lisbon, Portugal

15 (isabel.ramos@tecnico.ulisboa.pt)

${ }^{6}$ Alterra Wageningen UR, Droevendaalsesteeg 3, 6708 PB Wageningen, The Netherlands

17 (Dirk.Wascher@wur.nl, anne.schmidt@wur.nl)

${ }^{7}$ University of Florence, Via delle Pandette 29, 50127 Firenze, Italy (riccardo.simoncini@unifi.it)

Keywords: Geospatial indicators; Rural agrarian landscapes; Social and cultural values

\section{Research Highlights:}

- Including social values in EU agri-environment landscape indicators

- Introducing and testing the concept of 'societal awareness' as a measurable criteria

- Assessing the meaning, utility and performance of the landscape awareness indicator

- Identification of indicator weaknesses at regional level and proposed solutions

- Useful step to capturing societal interaction with landscape at a range of scales

There is increasing recognition that agricultural landscapes meet multiple societal needs and demands beyond provision of economic and environmental goods and services. Accordingly, there have been significant calls for the inclusion of societal, amenity and cultural values in agrienvironmental landscape indicators to assist policy makers in monitoring the wider impacts of landbased policies. However, capturing the amenity and cultural values that rural agrarian areas 
provide, by use of such indicators, presents significant challenges. The EU social awareness of landscape indicator represents a new class of generalized social indicator using a top-down methodology to capture the social dimensions of landscape without reference to the specific structural and cultural characteristics of individual landscapes. This paper reviews this indicator in the context of existing agri-environmental indicators and their differing design concepts. Using a stakeholder consultation approach in five case study regions, the potential and limitations of the indicator are evaluated, with a particular focus on its perceived meaning, utility and performance in the context of different user groups and at different geographical scales. This analysis supplements previous EU-wide assessments, through regional scale assessment of the limitations and potentialities of the indicator and the need for further data collection. The evaluation finds that the perceived meaning of the indicator does not vary with scale, but in common with all mapped indicators, the usefulness of the indicator, to different user groups, does change with scale of presentation. This indicator is viewed as most useful when presented at the scale of governance at which end users operate. The relevance of the different sub-components of the indicator are also found to vary across regions.

\section{Introduction}

Human activities have shaped the rural environment to such an extent that that the notion of the 'anthropocene', as a new geological epoch, has been proposed to describe the period since widespread agricultural management began (Crutzen and Stoermer, 2000). The multiple ways in which humans interact with rural agrarian landscapes makes landscapes multifunctional, providing a number of ecosystem services (MEA, 2005) to society, such as provisioning (e.g. food) and regulating (e.g. pollution control) services (Potschin and Haines-Young, 2006, Primdahl and Swaffield, 2010), but also a variety of cultural services, such as rural settlement, cultural heritage, and amenity (Bromley, 2000; Wascher, 2000; Beletti et al., 2002; Yrjölä and Kola, 2004). In recognition of the cultural services that rural agrarian landscapes provide, these landscapes are now being defined both as physical structures managed for agriculture and forestry and as cultural entities characterised by systems of land use and cultural practices. The functional components of the physical landscape (woodlands, hedges, field margins, ditches, etc.) as well as rural buildings and other structural elements (dry walls, terraces, etc.) are now understood to reflect the evolution of farming and forestry in a specific physical and socio-economic setting. Similarly, the cultural attributes of a landscape are a product of centuries of interaction between natural conditions, farming traditions and cultural heritage (Paracchini et al., 2012). 
1 Policies, in conjunction with economic forces, acting upon the social/cultural and the natural/manmade capital of a society, impact human activity and therefore have a marked impact on human wellbeing (Primdahl and Swaffield, 2010). Policies targeted at the rural space and related economic activities, such as the Common Agricultural policy (CAP) and environmental legislation, directly affect the provision of ecosystem services from rural agrarian landscapes, by driving changes to the management of these landscapes. Therefore, multi-dimensional indicators of the states and rates of change in agrarian landscapes are of particular interest to policy makers, as these are windows into the wider performance of these policy instruments.

To support policy monitoring and impact assessment, considerable research effort has been devoted in the past to mapping the physical components of European landscapes (Mücher et al., 2010; van Eupen et al., 2012; Wascher, 2005; Warnock and Griffiths, in press). In the EU this has resulted in maps identifying meaningful ecological units, based on differences in elevation, soils, geology and land cover, which provide broad environmental strata as a spatial framework to, or example, assist with indicator reporting and environmental sampling. A good example of this type of approach is the development in the UK of the Countryside Survey (Bunce et al. 1995), which provides a system of strata for monitoring environmental indicators at national scales, based on a rigorous sampling framework.

However, few reliable frameworks are currently available by which to assess the ways in which farming practices interact with landscapes to generate non-market, or non-commodity (MEA-Scope, 2003), cultural ecosystem services (Pinto Correia and Carvalho-Ribeiro, 2012). Consequently, there has been more limited development of indicators encompassing the social dimensions of rural agrarian landscapes (Cassatela and Peano, 2011b; Ode et al., 2008; Tveit et al., 2006). The European Landscape Convention (ELC, 2000) echoes others in describing this lack of a well-developed conceptual framework and limited policy tools as problematic given increasing awareness of the importance of accommodating multiple societal, amenity and cultural values in the management of landscapes (Haberl et al., 2004; Pinto-Correia and Breman, 2009; Pinto-Correia et al., 2006; Sassatelli, 2010; Stephenson, 2007, 2008; Swanwick, 2009). This paper, by testing the indicator for 'societal awareness of landscapes' developed by Paracchini et al. (this issue) at multiple scales of governance (i.e. regional and EU), provides an in-depth view on the potentialities for a top-down approach to the construction such social indicators of landscape.

\section{The current state of development of landscape social indicators}


1 Commenting on the state of development of social indicators of landscape Cassatella and Peano

2 (2011) point out that while a considerable number of social indicators exist, "the number of

3 indicators found in the literature is a sign of the diversity of use and the experimental phase the subject is currently going through, rather than a sign of rich content". While the corpus of existing social indicators is thus highly fragmented, due in part to this diversity of uses, a broad classification is possible on the basis of the criteria upon which public preferences for, or valuations of, landscapes are made, i.e. the functional value and the aesthetic value of landscapes.

Preferences for particular landscapes are sometimes expressed in terms of the uses to which landscapes can be put. So, for example, a landscape with land uses providing game-cover would have a 'functional value' to groups interested in hunting. Studies in the fields of landscape ecology and ecological economics have shown that different functional values can be attributed to the same landscapes according to the preferences of different user groups, such as tourists, farmers, hunters etc. (Ribe, 1989, 2002; Sheppard et al., 2001; Tahvanainen et al., 2001; Roovers et al., 2002; Rogge et al., 2007; Surova and Pinto-Correia, 2008; Sevenant, 2010; Carvalho-Ribeiro and Lovett 2011; Rogge et al., 2011). More recently, several EU research projects have contributed developments to the landscape function approach based on the ecosystem service framework (see for example, SENSOR: Helming et al., 2007; ELCAI: Perez-Soba and Wascher, 2005; Euroscape 2020: Wascher and Pedroli, 2008).

Preferences based on aesthetic values, on the other hand, are closely associated with the process of perception (Tahvanainen et al,. 2001), where these perceptions are rooted in cognitive processes, involving observation and analysis in the present, based on past knowledge and experience, to create coherent visual concepts that are attributable to, and identify, landscapes. Numerous landscape concepts have been identified, including, stewardship, coherence, disturbance, historicity, visual scale, imageability, diversity, naturalness and ephemera, etc. (Antrop, 2000; Ode et al., 2008, 2009, 2010, 2011, 2013; Fry et al., 2009). The role of human perception in defining landscapes has been recognised in the European Landscape Convention (ELC, 2000), which defines landscape as "an area perceived by people, whose character is the result of the action and interaction of natural and/or human factors" (COE, 2000). By their very nature, these perception-based values are multidimensional and localised, i.e. specific to particular groups and places and therefore the indicators which capture them are usually constructed using 'bottom-up' approaches, i.e. derived from data collected from local surveys addressing the preferences of publics related to particular rural agrarian landscapes (Carvalho-Ribeiro and Lovett, 2011; Hersperger and Burgi, 2009; Howley et al., 2012; 
Nijnik et al., 2009; Palang et al., 2011; Rogge et al., 2011; Sayadi et al., 2009; Surova and PintoCorreia, 2008; Van Eetvelde and Antrop, 2009). It has also been noted that both function and perception based values are not permanent, but context-related, such that individuals can switch between them according to circumstances, i.e. based on whether they are adopting a user/consumer or a citizens' viewpoint (van Rensburg et al., 2002; Vanslembrouck and Van Huylenbroeck, 2005).

Summing up the state of development of social indicators of landscape Cassatela and Peano (2011) note a number of generic weaknesses, two of which are of most relevance to this study. The first weakness is that, being derived from 'bottom-up' analytical processes, most existing social indicators cannot be aggregated, as they are relevant only at the local/regional level and in the context of spatially and temporally confined projects and so are not suitable for implementation across regions and at larger scales. Second, these indicators, while they attempt to capture particular anthropic phenomena, for example public perceptions of tranquility, diversity, uniqueness etc, use metrics that lack generalisable anchoring points, i.e. they are highly subjective. The need for exploration of more generalizable approaches to social indicator construction is thus apparent.

The CAP is, by some margin, the policy which has the greatest impact on the rural agrarian landscapes of Europe today (Primdahl and Swaffield, 2010). The purpose of defining indicator sets in the context of the CAP is to monitor and assess the effectiveness of the policy against its declared objectives. Two indicator sets have been made operational so far:

- The common monitoring and evaluation framework (CMEF), designed to measure and evaluate the impacts of all agricultural and rural development interventions, i.e. CAP Pillars I and II (CEC, 2006a), and

- Agri-environmental indicators (AEI), to monitor the integration of environmental concerns into the CAP (CEC, 2006b)

The AEI framework was designed to monitor the achievement of the goal set at the Cardiff European Council (1998) to integrate the environmental concerns into the CAP. By definition, the 28 distinct indicators of the AEI framework focus on the environment. However, while these include some indicators belonging to the social domain, these are only included to the extent necessary to explain why integration of environmental concerns into the CAP may, or may not, have occurred. The AEI therefore monitors issues such as farmers' training levels, use of environmental farm advisory services and risks of land abandonment. By contrast, the CMEF framework places social indicators into the mainstream, reflecting the fact that the CAP has specific objectives to improve the socio- 
economic condition of rural areas, for example 'Improving the competitiveness of the agricultural and forestry sector' and 'Improving the quality of life in rural areas'. While landscapes are specifically referenced in CAP policy, through stated policy objectives to restore, preserve and enhance the state of European landscapes, the AEI and CMEF frameworks contain only one indicator specifically targeted at landscape, i.e. the 'landscape state and diversity' indicator (AEI indicator number 28). Within this composite indicator a social component has been embedded, as a means to feeding relevant data into evaluations of the extent to which the social goals of the CAP, relating to rural landscapes, are being met. This social component is called the 'societal awareness of landscape' indicator. This indicator sets out to capture "the multiple ways society, as a whole, perceives, reads and assesses rural agrarian areas as well as its landscapes ... the ways society plans, manages, and uses the rural agrarian landscapes of Europe for productive or non-productive purposes" (Paracchini et al., 2012).

The societal awareness of landscape indicator captures three types of societal actions which are understood to reflect societal values concerning rural agrarian areas:

- Societal protections (in law) afforded to landscapes identified as common resource;

- In situ use of landscapes for recreational activities;

- Ex situ consumption of local quality products, derived from farming systems that directly maintain traditional landscapes.

The data on which the indicator is based include:

- the share of agricultural land under landscape protection designations, such as (NATURA2000, UNESCO World Heritage sites, IUCN category V World Protected Areas)

- the number of farms reporting agri-tourism activities

- the number, per unit area, of certified products with Protected Denomination of Origin (PDO) and Protected Geographical Indication (PGI) classifications linked maintenance of traditional landscapes, plus the area of quality wines (VQPRD - Vin de Qualité Produit dans des Régions Déterminées).

These three components have been normalized for scale and linearly aggregated to produce the final composite indicator. The exact choice of proxies used in the construction of the composite indicator has been driven by conceptual requirements, but constrained by quality and availability requirements for the input data, including the requirement that the data are: (i) available for all EU regions; and (ii) are already being collected and regularly updated for official purposes. 
1 This composite indicator is now 'operational' in a policy sense, as evidenced by Figure 1 below,

2 showing the indicator of societal awareness of rural agrarian landscapes, measured on 1-10 scale

3 and mapped across NUTS2 $2^{i}$ regions in the EU-27.

4

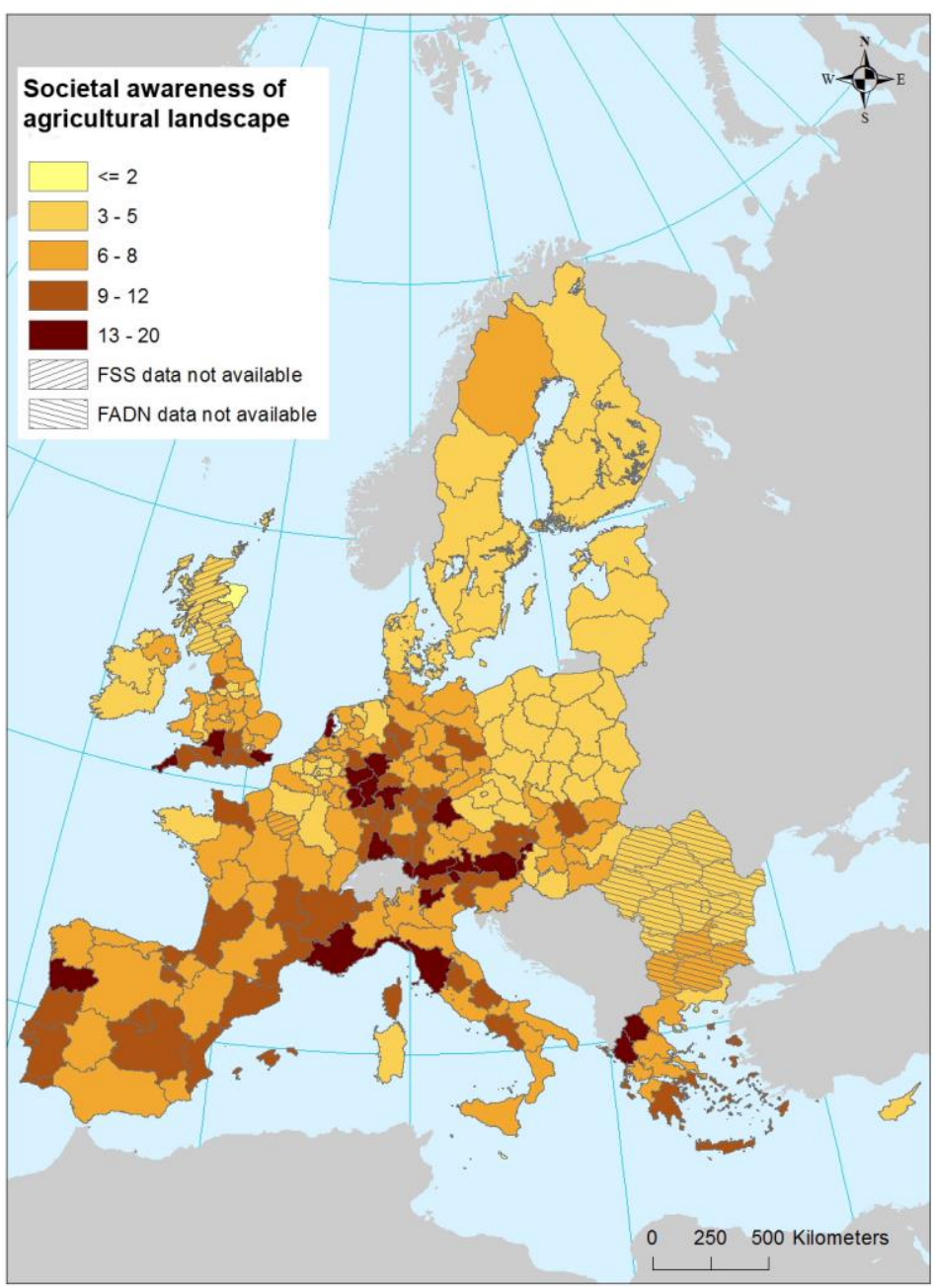

5

6 Figure 1: Societal awareness of landscape indicator per NUTS2 region in Europe.

7

8 The construction of the awareness indicator was not intended as a purely academic exercise. Rather

9 the indicator is intended for very practical purposes, i.e. for use by policy makers in informing their

10 evaluations of the efficacy of rural policies, particularly the CAP. This places certain minimum

11 functional and quality requirements on the indicator:-

- The indicator must capture a meaningful and relevant social phenomenon in a transparent way

- The indicator must be scalable, such that it can be applied at different levels of governance 
- The indicator must be stable, i.e. its meaning and utility must be maintained over different regions and at different scales. For example, to the extent that the indicator is driven by cultural norms and values and a complex set of subjective dispositions, does the meaning and utility of the indicator vary from country to country and region to region?

The top-down approach to the construction of the indicator is a clear departure from existing 'bottom-up' approaches. This indicator is consequently one of the few European-wide approaches to capture the socio-cultural interaction of whole societies with agrarian landscapes. This methodological and conceptual novelty means that these functional and quality minima cannot be assumed, and therefore have to be tested. The selection of a limited set of proxies to represent the whole phenomenon of societal awareness of landscapes, in part due to data availability, is a form of reductionism. In this case the dimensions captured might be seen as limited to aspects of use-value. In view of this, other questions automatically follow, such as: have all relevant dimensions of societal awareness been captured and if not, are accessible and reliable indicators of these missing dimensions available at the EU level?

\section{Methodology}

In order to analyze cross-scale issues, the societal awareness indicator was downscaled to the municipal level (Local Administrative Unit level 2 - LAU2 $2^{i i}$ ) in each of five case study areas in Europe, by applying the same methodology used to produce the EU-level indicator, as described in Paracchini et al., this issue. The case study regions have been selected to represent different agricultural management, landscape, and environmental contexts in the EU. The regions selected were: Alentejo (PT), Brabant (NL), Syddanmark (Southern Denmark: DK), Tuscany (IT) and West Midlands (UK). This downscaled indicator served two important functions:

- as a comparator for the indicator presented at NUTS2 level, so that differences in performance with changes in scale could be gauged

- as a comparator for alternative indicators which might be available at regional level, to test their performance relative to the existing composite indicator and its sub-components The core methodological approach to data acquisition was a stakeholder consultation exercise, by which expert judgments were obtained from a range of stakeholders on the research questions listed above. In order to carry out a detailed critical evaluation of the indicator, a number of evaluation criteria had to be identified, reflecting different user requirements. As there are no established frameworks of evaluation criteria that might be directly applied to this specific indicator, inspiration was drawn from the Bellagio Principles (ISSD, 1997). The Bellagio Principles are a comprehensive set of guidelines designed to assess progress towards sustainable development, 
1 covering the whole of the assessment process, including (i) the choice and design of indicators, (ii) their interpretation and (iii) communication of the result. These assessment criteria are collected into ten 'Principles' such as: perspective, scope, focus and openness, etc. each with 2-5 individual evaluation criteria. It proved impractical to assess the societal awareness of landscape indicator using each and every Bellagio evaluation criteria, in part because some of the evaluation criteria are inapplicable in this case, so three more generalised evaluation criteria were derived from a thematic clustering of Bellagio Principles, as shown in Table 1.

Table 1: Relevant Bellagio Principles addressing the three key assessment criteria

\begin{tabular}{|c|c|}
\hline $\begin{array}{l}\text { Primary assessment criteria } \\
\text { for the societal awareness of } \\
\text { landscape indicator }\end{array}$ & Relevant Bellagio Principles and subsidiary evaluation criteria \\
\hline $\begin{array}{l}\text { Meaning: does the indicator } \\
\text { measure something } \\
\text { meaningful? }\end{array}$ & $\begin{array}{l}\text { Principle } 2 \text { - Holistic perspective } \\
\text { - Includes a review of the whole system as well as its parts } \\
\text { Principle } 4 \text { - Adequate scope } \\
\text { - } \quad \text { Build on historic and current conditions to anticipate future } \\
\text { conditions } \\
\text { - Define the space of the study that is large enough to include local } \\
\text { and long distance impacts on people } \\
\text { - Adopt a time-horizon long enough to capture human and } \\
\text { ecosystem timescales } \\
\text { Principle } 6 \text { - Openness } \\
\text { Make explicit all judgements, assumptions and uncertainties }\end{array}$ \\
\hline Utility: Is the indicator useful? & $\begin{array}{l}\text { Principle } 7 \text { - Effective communication } \\
\text { - Be designed to address the needs of the audience and users } \\
\text { - Simplicity of structure and use of clear and plain language } \\
\text { Principle } 10 \text { - Institutional capacity } \\
\text { - Support development of local assessment capacity }\end{array}$ \\
\hline $\begin{array}{l}\text { Technical performance: Is the } \\
\text { indicator reliable? }\end{array}$ & $\begin{array}{l}\text { Principle } 5 \text { - Practical focus } \\
\text { - Comparing indicator values to targets, reference values, ranges, } \\
\text { thresholds or direction of trends as appropriate } \\
\text { - Standardising measurement wherever possible to permit } \\
\text { comparison } \\
\text { - A limited number of indicators or indicator combinations to } \\
\text { - } \text { provide a clear signal of progress } \\
\text { An explicit set of categories or an organising framework that links }\end{array}$ \\
\hline
\end{tabular}




\begin{tabular}{|c|c|} 
vision and goals to indicators \\
Principle 9 - Ongoing assessment \\
$\bullet \quad$ A capacity for repeated measurement to determine trends \\
$-\quad$ Be iterative, adaptive and responsive to change and uncertainty \\
because systems are complex and change frequently
\end{tabular}

1

The three generalised assessment criteria, derived from these principles, are as follows:

\section{Meaning}

The concept of societal awareness of landscape is relatively abstract and novel and is subtly different from more traditional concepts of landscape valuation (see above). It is therefore essential to ask: (a) what meaning do stakeholders attribute to the indicator; b) is the indicator meaning stable over different scales; (c) is the indicator meaningful and relevant to the social dimension of landscape?

\section{Utility (or usefulness)}

Who are the potential end users of the indicator and is the indicator constructed in such a way that it addresses the needs of these users operating in different regions and at different scales?

\section{Technical performance}

Two dimensions of technical performance are identified: (i) Comprehensiveness, i.e. the proportion of relevant 'events' that are captured by the indicator; and (ii) Accuracy, which includes such issues as the error count and modernity of the data.

Twenty-one stakeholders, with a minimum of two stakeholders in each of the five case study regions, were recruited to evaluate the indicator, on the basis of the above assessment criteria. Given the subtlety and novelty of the underlying concept, it was decided to perform, wherever possible, face-to-face interviews with the stakeholders, although this limited the number of participants that could be included in the process, due to resource constraints. Stakeholders were drawn from groups with particular expertise and interests in the current condition and future management of rural agrarian areas in their regions. These groups included local authority planners, national park officers, wildlife and conservation officers, agricultural and rural tourism officers etc. Stakeholders were provided with a briefing document that explained the design and purpose of the societal awareness of landscape indicator, or rather, as it was called at that time, the societal 'appreciation' of landscapes indicator, together with a mapping of the composite indicator and sub- 
1 indicators, for each of their case study regions. The stakeholders were then asked a set of common

2 evaluation questions. The basis of stakeholder judgements were comparisons of the indicator

3 mapped at NUT2 (Figure 1) and at LAU2 (regional) level (Figure 2).

4

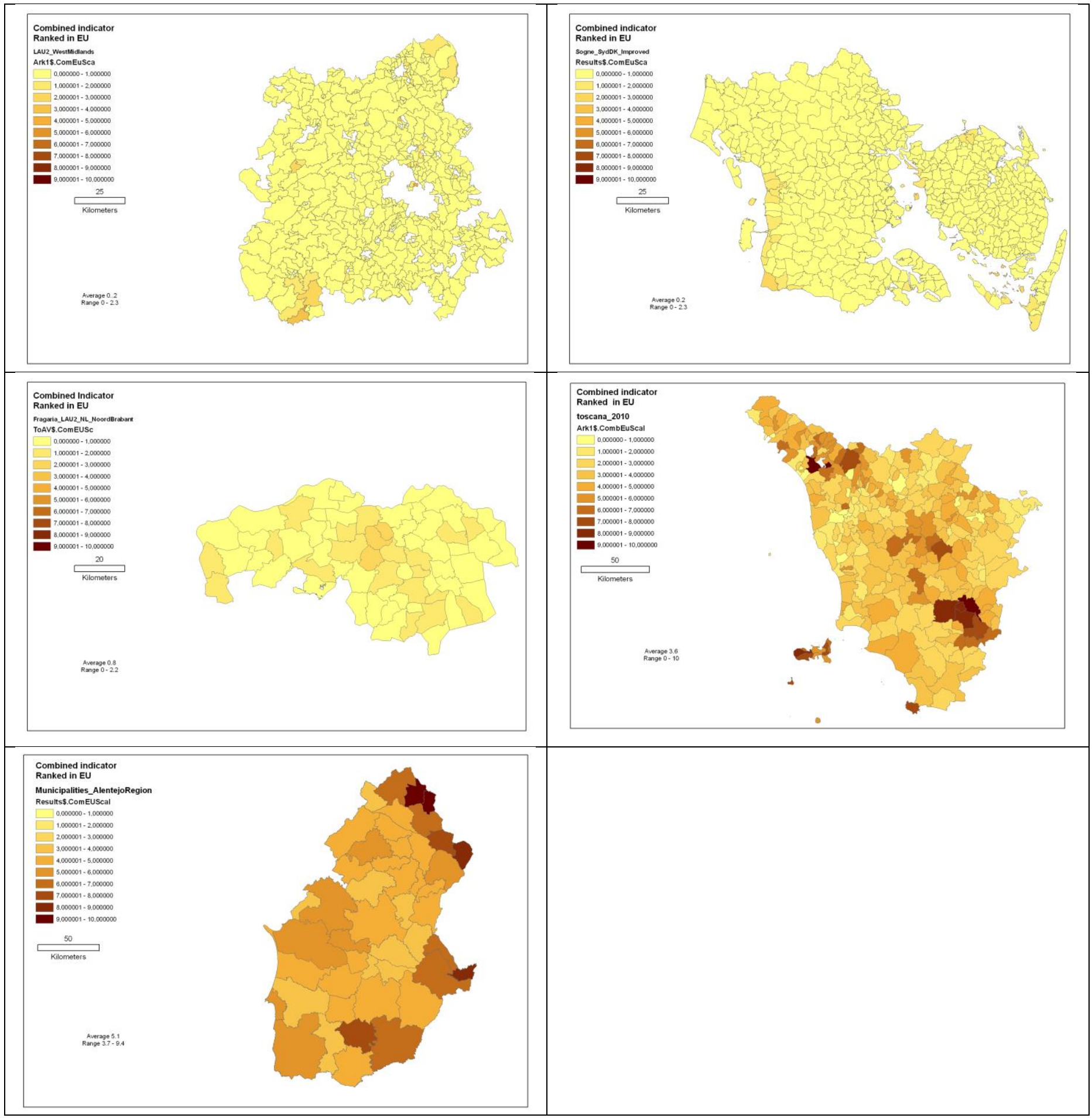

5 Figure 2: downscaled composite societal awareness indicator mapped at LAU2 level for 6 (from left to right) the East Midlands (UK), Syddanmark (South Denmark), Brabant (NL), 7 Tuscany (IT) and Alentejo (PT). 


\section{4. $\quad$ Results}

2

$3 \quad 4.1$ The meaning of the indicator (given and perceived meaning)

4 Because the concept of societal indicators is relatively novel, there is a risk that the meaning

5 attributed to it by individual stakeholders to the awareness indicator will vary from the meaning

6 intended by its designers. To assess this risk, stakeholders were asked to set aside the given label of

7 the indicator and suggest their own, based on its design and mapped outputs. As Table 3 shows, the

8 perceived meaning of the indicator is not consistent across stakeholders. Only 3 of the 21

9 stakeholders identified with the original label of the indicator, i.e. 'appreciation', and based on their understanding of its meaning numerous alternative labels were suggested. No single label dominated the thinking of stakeholders, although it could be argued that some labels combine readily into larger coherent complexes, such as 'valuation' and 'appeal'. There are two possible sources for this instability of meaning, the first being that users cannot take hold of this novel concept due to pre-conceptions about the nature of 'traditional' landscape valuation indices, and the use of traditional landscape maps (reflecting geophysical structures) in this type of exercise. The second potential source of instability is reflected in observations from stakeholders of incongruity between some of the concepts attached to the official label i.e. 'appreciation' and those attached to the proxies that make up the indicator, which appeared to them to be based on notions of valuation, especially in the case of the protected areas sub-indicator and to some extent the tourism subindicator.

Table 3: Frequency of stakeholder identification of different labels to capture the perceived meaning of the composite indicator, by region

\begin{tabular}{|l|l|l|l|l|l|l|}
\hline $\begin{array}{l}\text { Descriptive } \\
\text { label }\end{array}$ & $\begin{array}{l}\text { Syddanmark } \\
\text { (DK) }\end{array}$ & $\begin{array}{l}\text { West Mids. } \\
\text { (UK) }\end{array}$ & $\begin{array}{l}\text { Brabant } \\
\text { (NL) }\end{array}$ & $\begin{array}{l}\text { Tuscany } \\
\text { (IT) }\end{array}$ & $\begin{array}{l}\text { Alentejo } \\
\text { (PT) }\end{array}$ & Total \\
\hline Appreciation & & $\mathbf{1}$ & $\mathbf{2}$ & & & $\mathbf{3}$ \\
\hline Valuation & $\mathbf{1}$ & $\mathbf{1}$ & & & & $\mathbf{2}$ \\
\hline $\begin{array}{l}\text { Appeal / } \\
\text { potential appeal }\end{array}$ & & & & $\mathbf{1}$ & & $\mathbf{2}$ \\
\hline Awareness & & $\mathbf{2}$ & & & & $\mathbf{2}$ \\
\hline $\begin{array}{l}\text { 'Connection } \\
\text { with' }\end{array}$ & & $\mathbf{2}$ & & & & $\mathbf{2}$ \\
\hline Perception & & & & $\mathbf{1}$ & & $\mathbf{1}$ \\
\hline Familiarity & & & & & & \\
\hline Understanding & & $\mathbf{1}$ & & & & $\mathbf{1}$ \\
\hline Designation & $\mathbf{1}$ & & & & & $\mathbf{1}$ \\
\hline
\end{tabular}

The obvious conclusion to draw from this is that, to some extent, the perceived meaning of the indicator can differ from the intended meaning and be determined by the past experiences, knowledge, perceptions and requirements of the end-user. This opens the possibility that the 


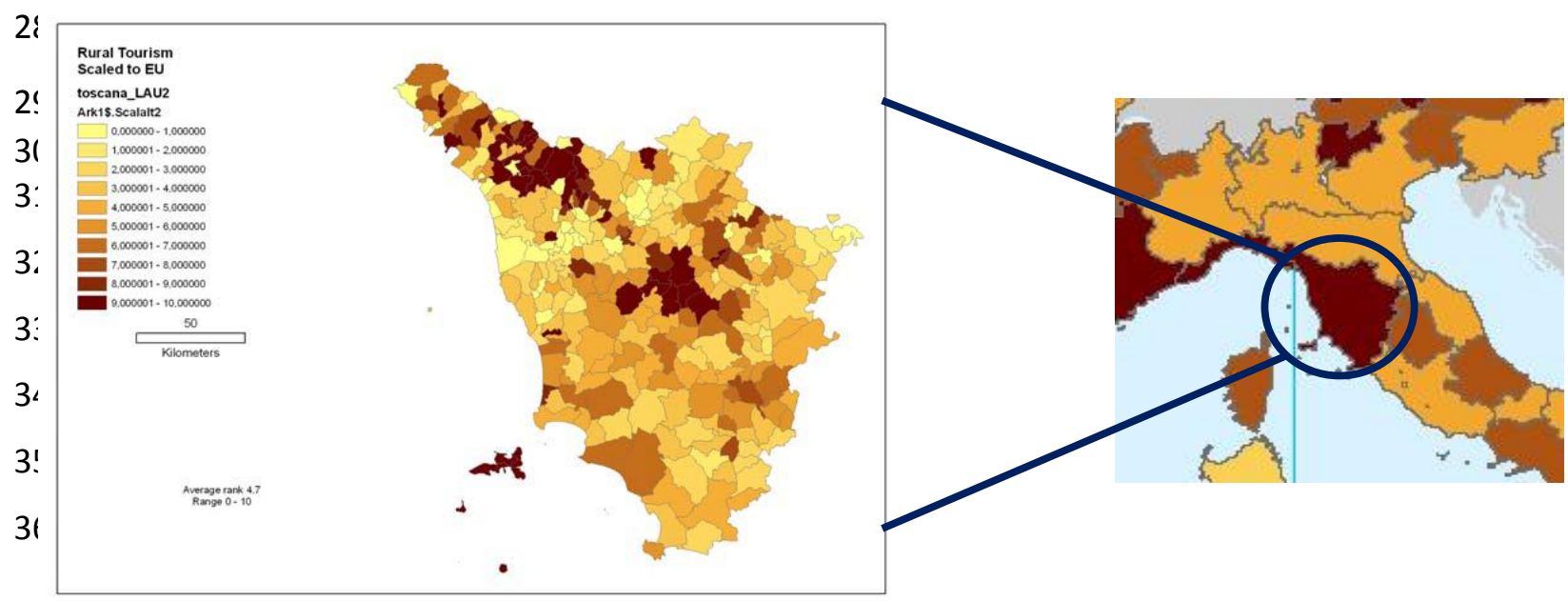

meaning of the indicator might change with scale of presentation because there may be different sets of end users, with different requirements for the indicator, operating at different scales. This question is reviewed further in the Discussion section.

\subsection{The utility of the indicator mapped at different scales}

Downscaling the composite indicator, and its subcomponents, to LAU2 level revealed that NUTS2 regions can contain highly differentiated zones. Figure 2 illustrates this by comparing the downscaled rural tourism proxy mapped at LAU2 level within the Tuscany region to the NUTS2 mapping of the same region. Stakeholders were quick to point out that most definable landscapes bear no relationship with the broad NUTS2 geo-political units, the great majority of which are smaller in extent than NUTS2. Therefore, expressing indicators at the NUTS2 level conflates multiple, potentially diverse landscapes, with key variations over landscapes not expressed. Mapped at LAU2 level, as Figure 2 demonstrates, clusters of adjoining LAU2 units become apparent, suggestive of possible landscape structures. In this particular example the clustering perhaps arises from the effect on the composite indicator of the certified products proxy. Looking at the results for all case study regions, there would appear to be a clear latitudinal effect relating to the spatial scale of PDO/PGI designations, with Mediterranean countries having products, especially wines, defined over small units (villages, municipalities, valleys etc.) and northern latitudes having local products, especially dairy products, defined over larger areas. For example, in the UK, PDO/PGI declarations are commonly phrased using a county descriptor (e.g. Shropshire Blue cheese), with counties lying between NUTS 2 and NUTS3. Because the LAU2 mapping better captured perceptions of interlandscape variation, stakeholders uniformly agreed that the utility of the composite indicator increased considerably at the LUA2 level and that the LAU2 indicator was the appropriate scale of mapping to support policy decisions at levels of governance below NUT2. 
2 Figure 3: Effect of downscaling the rural tourism indicator from NUTS2 to LAU2 for the Tuscany 3 region.

4.3 The utility of the indicator in different regions

There was some variation in the perceived utility of the composite indicator between NUTS2 regions. The results presented in Table 4 clearly show that the majority of stakeholders do not think that the composite indicator adequately reflects the 'real' societal awareness of landscapes in their region. Stakeholders in Tuscany believed that the indicator under-represents 'total' social awareness in their region, while stakeholders in the Netherlands were more inclined to think that the absolute level of awareness reflected by the indicator for their region was adequate.

Table 4: Frequency indicating that indicator does, or does not adequately represent societal awareness of landscape in each region at a scale from 1 (very low relevance) to 5 (very high relevance)

\begin{tabular}{|l|l|l|l|l|l|l|}
\hline & $\begin{array}{l}\text { Syddanmark } \\
\text { (DK) }\end{array}$ & $\begin{array}{l}\text { West Midlands } \\
\text { (UK) }\end{array}$ & Brabant (NL) & $\begin{array}{l}\text { Tuscany } \\
\text { (IT) }\end{array}$ & $\begin{array}{l}\text { Alentejo } \\
\text { (PT) }\end{array}$ & Total \\
\hline 'Yes', adequate & & & 1 & & & 1 \\
\hline 'No' inadequate & & 1 & 1 & 4 & & 6 \\
\hline
\end{tabular}

The composite indicator is based on a linear, un-weighted aggregation of three proxies. However, there was a strong sentiment amongst stakeholders that the relative importance and therefore, utility, of these three proxies, as expressions of societal awareness, varied by region (see Table 5). For example, in the Brabant region the market for certified products linked to specific landscapes and farming systems is undeveloped and therefore this particular proxy was viewed as having no usefulness for this area. The Certified products proxy was also given a low utility rating in the West Midlands, perhaps because the type of product produced in the region, for example cheeses, have large defined production areas compared to products such as wines, which are important for Tuscany and Alentejo. In all case study areas the perceived utility of the farm tourism proxy is low relative to the other two proxies.

Table 5: Average rank of the relevance of each proxy as a measure of societal awareness in each case study region (on a 5-point scale where 5=highest rank) 


\begin{tabular}{|l|l|l|l|l|l|l|}
\hline & $\begin{array}{l}\text { Syddanmark } \\
\text { (DK) }\end{array}$ & $\begin{array}{l}\text { West } \\
\text { Midlands } \\
\text { (UK) }\end{array}$ & Brabant (NL) & $\begin{array}{l}\text { Tuscany } \\
\text { (IT) }\end{array}$ & $\begin{array}{l}\text { Alentejo } \\
\text { (PT) }\end{array}$ & $\begin{array}{l}\text { Average rank } \\
\text { over all regions }\end{array}$ \\
\hline Protected areas & 4.3 & 4.3 & 3 & 2.5 & 3.7 & 3.5 \\
\hline $\begin{array}{l}\text { Certified } \\
\text { products }\end{array}$ & 3.0 & 2.5 & N.A. & 4.3 & 3.7 & 3.4 \\
\hline Farm tourism & 2.0 & 2.7 & 3.5 & 3.5 & 3.4 & 3.0 \\
\hline
\end{tabular}

\subsection{The technical performance of the composite indicator}

Technical performance was assessed in terms of: (i) Comprehensiveness, which reflects the proportion of targeted events that are captured by the indicator; and (ii) Accuracy, reflecting such issues as the error count and modernity of the data (how up-to-date the data are), both of which are impacted by the data collection methodology (survey or census) and the frequency of measurement. Only one of the three proxies is singled out as having potential problems in terms of comprehensiveness, i.e. the farm tourism proxy which, as Table 4 shows, obtains a low stakeholder rating relative to the other proxies. In this case the perceived problem stems from the fact that the proxy is based on data solely for farm tourist activity, when this measure is acknowledged to capture only a fraction of the tourist activity in rural areas. Stakeholders from the Tuscany case study region cited one marked effect of this limitation, pointing out that because of the normalisation of number of farms with tourism activity to areas with very a small percentage of utilized agricultural area (UAA), the rural tourism proxy generates similar scores for the Appenine region, the Island of Elba and the central Chianti region when in fact these regions differ very significantly in terms of rural tourism (see Fig. 3).

The evaluation of the modernity of the proxy data is based on the rate of change in the phenomenon being measured. For proxies such as protected areas, rates of change in the data are likely to be very slow, while for the other proxies data may change quite rapidly. However, it has to be accepted that there are practical constraints on the frequency with which new measurement exercises can occur, and as new measurements were already being undertaken annually there were no concerns raised by stakeholders over the modernity and rates of updating of these proxies.

Table 6: Average rank of the comprehensiveness (i.e. captures all relevant cases) of each of the three proxies in each case study region at a scale from 1 (very low relevance) to 5 (very high relevance)

\begin{tabular}{|l|l|l|l|l|l|l|}
\hline & Syddanmark & West & Brabant (NL) & Tuscany & Alentejo (PT) & Average \\
\hline
\end{tabular}




\begin{tabular}{|l|l|l|l|l|l|l|}
\hline & (DK) & $\begin{array}{l}\text { Midlands } \\
\text { (UK) }\end{array}$ & & (IT) & & $\begin{array}{l}\text { rank over all } \\
\text { regions }\end{array}$ \\
\hline Protected areas & 4.3 & 3.7 & 3.5 & 1.3 & 3.8 & 3.3 \\
\hline $\begin{array}{l}\text { Certified } \\
\text { products }\end{array}$ & 4.0 & 1.3 & N.A. & 3 & 3.4 & 2.9 \\
\hline Farm tourism & 3.5 & 2.0 & 3 & 1.3 & 2.6 & 2.5 \\
\hline
\end{tabular}

1

2

3

4

5

6

7

8

9

10

11

12

Table 7: Search results for alternative social landscape proxies available Europe-wide

\begin{tabular}{|l|l|l|l|l|}
\hline & \multicolumn{2}{|c|}{ Tourism in rural areas } & $\begin{array}{l}\text { Agricultural areas in protected and } \\
\text { valuable sites }\end{array}$ \\
\hline $\begin{array}{l}\text { Indicator } \\
\text { description }\end{array}$ & $\begin{array}{l}\text { Tourism intensity } \\
\text { in agricultural } \\
\text { areas }\end{array}$ & $\begin{array}{l}\text { POI camp sites in } \\
\text { agricultural areas }\end{array}$ & $\begin{array}{l}\text { Agricultural land } \\
\text { use in protected } \\
\text { sites }\end{array}$ & $\begin{array}{l}\text { Appreciation of } \\
\text { cultural heritage }\end{array}$ \\
\hline $\begin{array}{l}\text { Unit of } \\
\text { measurement }\end{array}$ & $\begin{array}{l}\text { Percentage of } \\
\text { total income } \\
\text { derived from } \\
\text { tourist activity }\end{array}$ & $\begin{array}{l}\text { Number of camp } \\
\text { sites }\end{array}$ & $\begin{array}{l}\text { Percentage of } \\
\text { agricultural land } \\
\text { in protected sites }\end{array}$ & Area percentage \\
\hline $\begin{array}{l}\text { Spatial } \\
\text { reference }\end{array}$ & NUTS 2/3 & LAU2 & NUTS 3 & $\begin{array}{l}\text { NUTS 2/3/ Corine } \\
\text { CC }\end{array}$ \\
\hline
\end{tabular}




\begin{tabular}{|l|l|l|l|l|}
\hline Data source & FADN & $\begin{array}{l}\text { TomTom } \\
\text { (www.tomtom.com } \\
\text { (wwine CC \& } \\
\text { - permission to use } \\
\text { acknowledged by } \\
\text { TomTom) }\end{array}$ & $\begin{array}{l}\text { Corignated Area } \\
\text { Designat Tourism }\end{array}$ & $\begin{array}{l}\text { data \& } \\
\text { Designated Area } \\
\text { Database }\end{array}$ \\
& & & \\
\hline
\end{tabular}

1

2 On the issue of whether each of the proxies reflected in the composite indicator were appropriate to

Table 8: Average rank of the meaningfulness of each of the three proxies contributing to the composite indicator of societal awareness of landscape in each case study region (where $1=$ very low relevance and $5=$ very high relevance)

\begin{tabular}{|l|l|l|l|l|l|l|}
\hline & $\begin{array}{l}\text { Syddanmark } \\
\text { (DK) }\end{array}$ & $\begin{array}{l}\text { West } \\
\text { Midlands } \\
\text { (UK) }\end{array}$ & Brabant (NL) & $\begin{array}{l}\text { Tuscany } \\
\text { (IT) }\end{array}$ & $\begin{array}{l}\text { Alentejo } \\
\text { (PT) }\end{array}$ & $\begin{array}{l}\text { Average } \\
\text { rank over } \\
\text { all regions }\end{array}$ \\
\hline Protected areas & 4.0 & 3.5 & 2 & 1.7 & 3.9 & 3.0 \\
\hline $\begin{array}{l}\text { Certified } \\
\text { products }\end{array}$ & 3.7 & 2.5 & N.A. & 3.3 & 3.9 & 3.4 \\
\hline Farm tourism & 2.3 & 2.5 & 3 & 2.3 & 3.5 & 2.7 \\
\hline
\end{tabular}

Table 9: Measures from regional datasets reflecting potential alternatives dimensions of societal awareness of rural agrarian landscapes

\begin{tabular}{|l|l|l|l|l|l|l|l|}
\hline & \multicolumn{2}{|c|}{ West Midlands (UK) } & $\begin{array}{l}\text { Brabant } \\
\text { (NL) }\end{array}$ & $\begin{array}{l}\text { Syddanmark } \\
\text { (DK) }\end{array}$ & \multicolumn{2}{|c|}{ Alentejo (PT) } & Tuscany (IT) \\
\hline $\begin{array}{l}\text { Dataset / } \\
\text { indicator }\end{array}$ & $\begin{array}{l}\text { Scheduled } \\
\text { Ancient } \\
\text { Monuments }\end{array}$ & $\begin{array}{l}\text { Listed } \\
\text { Buildings }\end{array}$ & $\begin{array}{l}\text { Appreciated } \\
\text { Landscapes }\end{array}$ & $\begin{array}{l}\text { Rural } \\
\text { Landscapes }\end{array}$ & $\begin{array}{l}\text { Landscape } \\
\text { Diversity }\end{array}$ & $\begin{array}{l}\text { Complex } \\
\text { Patterns }\end{array}$ & $\begin{array}{l}\text { Countryside } \\
\text { itineraries }\end{array}$ \\
\hline Source & & & $\begin{array}{l}\text { Survey: My- } \\
\text { Place-To-Be }\end{array}$ & LPIS & Corine & $\begin{array}{l}\text { Corine } \\
\text { class 242 }\end{array}$ & $\begin{array}{l}\text { Regione } \\
\text { Toscana } \\
\text { (2014) }\end{array}$ \\
\hline
\end{tabular}


2

3

4

5

6

7

8

\begin{tabular}{|l|l|l|l|l|l|l|l|}
\hline $\begin{array}{l}\text { Maximum } \\
\text { available } \\
\text { resolution }\end{array}$ & & LAU2 & LAU2 & NUTS2 & NUTS2 & LAU2 \\
\hline
\end{tabular}

\section{Discussion}

Because the use of indicators capturing the social dimensions of landscape in policy analysis is relatively novel many of the stakeholders in this study struggled to set aside the more traditional concepts of landscape preference and valuation when dealing with the new indicator. This problem appears to be accentuated by stakeholders' perceptions that two of the proxies contributing to the composite indicator are themselves forms of valuation. This difficulty in grasping the intended meaning of the indicator was found to be more acute at finer scales of presentation, perhaps because at this level the indicator is most readily associated with identifiable physical landscapes about which preferences have already been formed. The risk inherent in this is that at different scales and in different regions, stakeholders may bias the indicator's given meaning, according to their own experiences and understandings. This problem was compounded somewhat by the fact that the label first attached to the indicator, i.e. 'appreciation', reads into notions of pre-cognitive processes of feeling and liking (i.e. preferences). The revised label for the indicator, i.e. 'awareness', goes some way to reducing this problem, as it is more related to embedded knowledge and past experience, and as such more clearly conveys the designers' original conception of the indicator.

While the composite indicator is billed as capturing 'awareness', of landscapes in a very broad sense, i.e. as expressed by society as a whole, there is of course no assurance that all expressions of awareness are being captured and indeed other expressions of awareness might be envisioned, for example representations of landscapes in the media, including social media. Unfortunately, at the present time, insufficient data exist to allow for the incorporation into the indicator of these other possible expressions of societal awareness. However, further exploration of these issues is recommended (Wood, et al., 2013). For the present then, it must be concluded that the AEI composite indicator of societal awareness of agrarian landscapes captures the only dimensions of this phenomenon that can be reliably measured.

Since the choice of the proxies used in the indicator was constrained by the availability of existing data (Paracchini et al., this issue) it is inevitable that these measures would not fully capture all of the events relevant to the dimension that they present. It hardly needs stating that all proxies could, 
in a perfect world, capture the relevant events within their specified dimensions better than they do. However, in this case, the farm tourism proxy was singled out as being most in need to remedial work, to reduce potential bias caused by the weakness of this proxy, through the inclusion of other rural tourism-related events, particularly where the addition of these proxies overcomes the current singular focus on farm tourism. The important point to note, however, is that limitations of this kind do not reflect a flaw in the composite indicator concept, but are merely implementation issues and amendable to resolution through the use of datasets available at more local scales.

There was a consensus among stakeholders that the utility of the composite indicator increased as the scale of presentation decreased, and an acknowledgement that expressing the landscape indicator solely at NUTS2 risks conflating multiple, potentially diverse landscapes. Stakeholders were concerned that if regionally important landscapes are not visible, they may be subject to inappropriate policy decisions. The ELC defines landscape as '... an area, as perceived by people' (ELC, 2000) and in this sense landscape is not solely a physical phenomenon with a single objective reality, but a cultural one with a set of subjective realities (Jackson, 1979), reflecting the so-called 'cultural values' model of landscape (Olwig, 2005). In view of this, stakeholders may be placing maximum utility at the level at which they perceive landscapes to exist. Additionally, these stakeholders were not operating at the geographical scale of EU policy makers and therefore may place maximum utility at the scale at which they themselves are concerned with governance. This issue of the utility of an indicator varying with the scale at which it is presented is, of course, common to all mapped indicators. Because the study has demonstrated that the indicator can be reliably presented at multiple scales of resolution, it can be scaled to suit the needs of policy makers and other stakeholders operating at a range of scales of governance.

The traditional approach to understanding appreciation and awareness of landscapes is through the use of local case studies to capture local dynamics. This approach has predominated because of the weight of evidence that peoples' attitudes to, and perceptions of, landscape are place-specific (Scott and Benson, 2002; Swanwick, 2002; Swanwick, 2009). It is very probable therefore, that the way in which awareness of landscapes is expressed will also vary between societies. This study has shown that the current use of a constant relative weighting for the three proxies of awareness in all regions potentially neglects these local dynamics and therefore should be reviewed. For example, using an un-weighted aggregation of proxies, much higher awareness scores occur in the two Southern European regions, Alentejo and Tuscany, than in the more northern Brabant and Syddanmark regions. This is due to the fact that in the northern regions the quality products proxy has very little 
relevance because of an absence of quality products with a link to landscape. The way in which the indicator has been constructed does not preclude the application of variable weights to proxies on a regional basis, and therefore the representativeness of the indicator can be improved in this manner, assuming that relevant data, available across the whole EU, can be sourced on which to base such weights.

\section{Conclusions}

There are few precedents for the construction of geospatial, continent-wide indicators of cultural landscapes, with Mücher et al. (2010) providing one of the few available. Consequently, there has been little developmental analysis of these constructs. The EU composite societal awareness of landscape indicator is undoubtedly a useful step in this direction. The indicator has demonstrated that this social phenomenon can be captured using a top-down data gathering approach and that the indicator so constructed is sufficiently meaningful and reliable for use in policy analysis at various scales of governance. Indeed the indicator reveals itself to be more holistic in conception than it first appears, as an analysis of its components reveal that it captures both the use-value dimension of social values and pre-cognitive preference. The use-value dimension is captured through reflection of in situ and ex situ consumption of: (i) landscape amenity and (ii) agricultural products linked to particular landscapes, while pre-cognitive preference is expressed through landscape designations, i.e. based on the principle of 'if society protects, then society values'. In this sense 'awareness' can be understood as the knowledge and experience-based foundation to all these other perceptions and functional relationships with rural agrarian landscapes and is therefore, perhaps, the ideal proxy to represent them.

That said, further work needs to be done to develop this and other social indicators to ensure capture of more of the many forms of interaction with rural agrarian areas that are expressed by society at different scales and in different regions (Ode et al., 2009, Pelosi et al., 2010). A number of issues have been identified in this study leading to beneficial improvements to the indicator. Some of these issues are of a practical nature and obvious short-term solutions present themselves, while others will require further conceptual development over the longer term. In the short term, the following developments might be suggested:

- the landscape protection proxy does not capture some productive landscapes, especially accessible areas, that society might be widely aware of. The addition of national landscape designations to this proxy, complementing the existing EU designations, should therefore be considered; 
- the use of weights for each of the proxies contributing to the indicator should be considered, based on their relative importance in expressing societal awareness of landscape in different regions. These weights might be generated through stakeholder consultation exercises or surveys of regional publics;

- the NUTS2 composite indicator is recognised as being a useful tool for EU policy makers, but the expression of the indicator at lower governance levels is also recommended, so that different stakeholders can find a scale that is suitable for them;

- the rural tourism proxy should be buttressed with other tourism proxies, capturing the widest possible range of tourist activities associated with agrarian landscapes. Further research might consider the potential of such measures as: numbers of rural restaurants, availability of non-farm small-scale accommodation, number of visitors in agricultural areas using trails and footpaths and associated car parks etc.

- Some consideration should be given to the normalization method used to scale the indicator when the indicator is being mapped at scales lower than NUTS2. It is apparent that the 0-10 scale currently used, when normalized at the EU level, i.e. the so-called 'pooled' normalization, when applied to regions with indicator scores well below the EU average, does not reveal some variation between landscapes that publics in those regions may identify as significant.

Stakeholder perception was that the utility of the indicator increases with reduction in the scale of mapping, due to the greater level of within-region variation revealed. These stakeholders operate locally and therefore have a greater depth of awareness and understanding of the landscapes represented within their regions, based on stories, genealogies and an understanding of historic and current management practices, than do 'outsiders' (Stephenson, 2008). This provides added support for the view that societal awareness of agrarian landscapes might be at its richest when expressed by locals at the local level. Future research into mapped indicators of social interaction with agrarian landscapes should therefore explore ways of capturing this, as yet largely uncharted realm of human interaction with landscapes, i.e. collecting into one measure numerous local expressions of interaction with agrarian landscape. This might be done, for example, by including within the composite indicator proxies such as local protection designations, or density of rights of way etc.

The CAP is without doubt one of the primary drivers of landscape change, but it is not the only driver of changing societal attitudes to landscape. Perhaps the most cognitively challenging question arising from the development of this indicator is how to distil from observed changes in the state of 
the societal awareness indicator the specific role of public interventions, and in particular CAP.

Societal awareness is fully anthropocentric and values attached to any measure(s) of this phenomenon will evolve through time with changing societal values and developments in culture more broadly (Paracchini et al., 2014, this issue). More specifically, cultural attitudes will be driven by science and policy, but also socio-economic factors. Observation suggests that these broad societal changes will lead to an increasing disconnection with the landscape and changes to the way that society expresses awareness of landscape (Stephenson, 2007, 2008). Policy makers therefore need to recognise that the dimensions along which society expresses awareness of landscape may change, requiring new proxy indicators and new views on the balance between proxies (longitudinal change, as well as cross-sectional change)(Turpin et al., 2009; van Eupen et al., 2012).

\section{Acknowledgements}

The study on which this paper was based (EUR $25192 \mathrm{EN}$ ) was supported with funding from the Institute for Environment and Sustainability, Joint Research Centre of the European Commission.

\section{References}

Antrop, M. 2000. Background concepts for integrated landscape analysis. Agriculture Ecosystems and Environment_77, 17-28.

Belletti, G., G. Brunori, A. Marescotti and Rossi, A. 2002. Individual and collective levels in multifunctional Agriculture. SYAL Colloquium 'Local Agri-food Systems: products, enterprises and local dynamics', Montpellier, France.

Bromley, D.W., 2000. Can agriculture become and environmental asset? World economics, 1(3), 127-139.

Bunce, R.G.H. and Barr, C.J. 1995. The Great Britain Countryside Survey and its potential for coordination of vegetation and countryside data in Europe. In: Griffiths, G.H. (Eds.) Landscape ecology: theory and application. Aberdeen, International Association for Landscape Ecology (UK), 21-23.

Carvalho-Ribeiro, S. M. and Lovett, A (2011). Is an attractive forest well managed? Correlating public preferences for forests across rural/urban gradients. Forest Policy and Economics 13, 46-54.

Cassatela, C. and Peano, A. 2011. Landscape Indicators: Assessing and Monitoring landscape quality. Springer Books, $105-140$.

CEC 2006a. COMMISSION REGULATION (EC) No 1974/2006 of 15 December 2006 laying down detailed rules for the application of Council Regulation (EC) No 1698/2005 on support for rural 
development by the European Agricultural Fund for Rural Development (EAFRD) - Annex VIII. Official Journal of the European Union L 368/15.

CEC 2006b. Development of agri-environmental indicators for monitoring the integration of environmental concerns into the common agricultural policy. COM(2006)508 final, Brussels. Available at http://eur-lex.europa.eu/LexUriServ/LexUriServ.do?uri=COM:2006:0508:FIN:EN:PDF. Accessed 18th March 2014.

Crutzen, P.J. and Stoermer, E.F. 2000. The Anthropocene. Global Change Newsletter 41, 17-18.

ELC 2000. The European Landscape Convention. Council of Europe, Strasbourg. http://ec.europa.eu/regional policy/consultation/terco/paper terco en.pdf

Eetvelde, V. van and Antrop, M. 2009. Indicators for assessing changing landscape character of cultural landscapes in Flanders (Belgium). Land Use Policy 26(4), 901-910.

Eupen, M. van, Metzger, M. J., Pérez-Soba, M., Verburg, P. H., Doorn, A. van and Bunce, R. G. H. 2012. A rural typology for strategic European policies. Land Use Policy 29(3), 473-482.

Fry, G., Tveit, M. S., Ode, A. and Velarde, M. D. 2009. The ecology of visual landscapes: Exploring the conceptual common ground of visual and ecological landscape indicators. Ecological Indicators 9(5), 933-947.

Helming, K., Tabbush, P. and Perez-Soba, M. (Eds.) 2007. Sustainability Impact Assessment of Land Use Changes. Springer Verlag, Berlin, pp 507.

Haberl, H., Wackernagel, M., Wrbka, T. 2004. Land use and sustainability indicators. An introduction. Land Use Policy 21, 193-198.

Hersperger, A. M. and Burgi, M. 2009. Going beyond landscape change description: Quantifying the importance of driving forces of landscape change in a Central Europe case study. Land Use Policy 26(3), 640-648.

Howley, P., Donoghue, C. O. and Hynes. S. 2012. Exploring public preferences for traditional farming landscapes. Landscape and Urban Planning 104(1), 66-74.

ISSD 1997. Assessing Sustainable Development: Principles in Practice. The International Institute for Sustainable Development, Winnipeg, Manitoba, 1997. (https://www.iisd.org/pdf/bellagio.pdf)

Jackson, J. B. 1979. Landscape as Theater. Landscape and Urban Planning 23(1), 3-7.

MEA-Scope 2003. Micro-economic instruments for impact assessment of multifunctional agriculture to implement the Model of European Agriculture: a Policy Oriented Research Project of the Sixth Framework Programme. European Commission. (http://www.mea-scope.org/) 
Mucher, C.A., Klijn, J.A., Wascher, D.W. and Schaminée, J.H.J. 2010. A new European Landscape Classification (LANMAP) - a transparent, flexible and user-oriented methodology to distinguish landscape. Ecological Indicators 10, 87-103.

Nijnik, M., Zahvoyska, L. Nijnik. A. and Ode, A. 2009. Public evaluation of landscape content and change: Several examples from Europe. Land Use Policy 26(1), 77-86.

Ode, A., Fry, G., Tveit, M.S., Messager, P. and Miller, D. 2009. Indicators of perceived naturalness as drivers of landscape preference. Journal of Environmental Management 90(1), 375-383.

Ode, A., Hagerhall, C. M. and Sang, N. 2010. Analysing Visual Landscape Complexity: Theory and Application. Landscape Research 35(1), 111-131.

Ode, A. and Miller, D. 2011. Analysing the relationships between indicators of landscape complexity and preference. Environmental Planning B: Planning \& Design 38, 24-40.

Ode, A., Tveit, M. S. and Fry. G. 2008. Capturing landscape visual character using indicators: Touching base with landscape aesthetic theory. Landscape Research 33(1), 89-117.

Ode Sang, Å. and Tveit, M. S. 2013. Perceptions of stewardship in Norwegian agricultural landscapes. Land Use Policy 31(0), 557-564.

Olwig, K. R. 2005. Editorial: Law, Polity and the changing meaning of landscape. Landscape Research 30(3), 293-298.

Palang, H., Alumäe, H. Printsmann, A., Rehema, M., Sepp, K. and Sooväli-Sepping, H. 2011. Social landscape: Ten years of planning 'valuable landscapes' in Estonia. Land Use Policy 28(1), 19-25.

Paracchini, M. L., Capitani, C. , Schmidt, A. M., Andersen, E., Wascher, D. M., Jones, P. J., Simoncini, R., Carvalho Ribeiro, S., Griffiths, G. H., Mortimer, S. R., Madeira, L,. Loupa Ramos, I. and Pinto Correia, T. 2012. Measuring societal awareness of the rural agrarian landscape: indicators and scale issues. EUR 25192 EN - 2012, Joint Research Centre, European Commission.

Pelosi, C., Goulard, M., and Balent, G. 2010. The spatial scale mismatch between ecological processes and agricultural management: Do difficulties come from underlying theoretical frameworks? Agriculture, Ecosystems and Environment 139(4), 455-462.

Perez-Soba, M. and Wascher, D.M. (Eds.) 2005. Landscape Character Areas - places for building a sustainable Europe: Policy Brochure. European Landscape Character Assessment Initiative (ELCAI), 5th Framework Programme, pp 33.

Pinto-Correia, T. and Breman, B. 2009. The new roles of farming in a differentiated European countryside: contribution to a typology of rural areas according to their multifunctionality. Application to Portugal. Regional Environmental Change 3(9), 143-152. 
Pinto Correia, T. and Carvalho-Ribeiro, S. M. 2012. The Index of Function Suitability (IFS). A new tool for assessing the capacity of landscapes to provide amenity functions. Land Use Policy 29(1), 2334.

Pinto-Correia, T., Gustavsson, R. and Pirnat, J. 2006. Bridging the gap between centrally defined policies and local decisions. Towards more sensitive and creative rural landscape management. Landscape Ecology 21, 333-346.

Potschin, M. B. and Haines-Young, R. H. 2006. Landscapes and sustainability. Landscape and Urban Planning 75(3-4): 155-161.

Primdahl, J. and Swaffield, S. 2010. Globalisation and Agricultural Landscapes. Change Patterns and Policy Trends in Developed Countries. Cambridge, Cambridge University Press.

Rensburg, T.M. van, Mill, G.A., Common, M. and Lovett, J. 2002. Preferences and multiple use forest management. Ecological Economics 43 (2-3), 231-244.

Ribe, R. G. 1989. The aesthetics of forestry: What has empirical preference research taught us?" Environmental Management 13(1), 55-74.

Ribe, R. G. 2002. Is scenic beauty a proxy for acceptable management? The influence of environmental attitudes on landscape perceptions. Environment and Behavior 34(6), 757-780.

Rogge, E., Dessein, J. and Gulinck, H. 2011. Stakeholders perception of attitudes towards major landscape changes held by the public: The case of greenhouse clusters in Flanders. Land Use Policy 28(1), 334-342.

Rogge, E., Nevens, F. and Gulinck, H. 2007. Perception of rural landscapes in Flanders: Looking beyond aesthetics. Landscape and Urban Planning 82(4), 159-174.

Roovers, P., Hermy, M. and Gullink, H. 2002. Visitor profile, perceptions and expectations from a gradient of increasing urbanisation in central Belgium. Landscape and Urban Planning 59, 129145.

Sassatelli, M. 2010. European Identity between Flows and Places : Insights from Emerging European Landscape Policies. Sociology 44(1), 67-83.

Sayadi, S., Gonzalez-Roa, M. C. and Calatrava-Requena, J. 2009. Public preferences for landscape features: The case of agricultural landscape in mountainous Mediterranean areas. Land Use Policy 26, 334-344.

Scott, K. and Benson, F. 2002. Public and Professional Attitudes to Landscape. Newcastle, University of Newcastle. 
Sevenant, M. 2010. Variation in landscape perception and preference: Experience from case studies in rural and urban landscapes observed by different groups of respondents. Unpublised PhD thesis, University of Ghent.

Sheppard, S. R. J., Harshaw, H. W. and McBride, J. R. 2001. Priorities for reconciling sustainability and aesthetics in forest landscape management. In: Sheppard, S. and Harshaw, H. (Eds.) Forests and lansdcapes-linking ecology, sustainability and aesthetics. CABI in association with IUFRO, Wallingford, Oxon, 263-287.

Stephenson, J. 2007. Many perceptions, one landscape. Landscape Review 11(2), 9-30.

Stephenson, J. 2008. The cultural values model: An integrated approach to values in landscapes. Landscape and Urban Planning 84(2), 127-139.

Surova, D. and Pinto-Correia, T. 2008. Landscape preferences in the cork oak Montado region of Alentejo, southern Portugal: Searching for valuable landscape characteristics for different user groups. Landscape Research 33(3), 311-330.

Swanwick, C. 2002. Landscape Character Assessment. Guidance for England and Scotland, Scottish Natural Heritage.

Swanwick, C. 2009. Society's attitudes to and preferences for land and landscape. Land Use Policy 26(Supplement 1), S62-S75.

Tahvanainen, L., Tyrvainen, L., Ihalainen, M., Vuorela, N. and Kolehmainen, O. 2001. Forest management and public perceptions - visual versus verbal information. Landscape and Urban Planning 53(1-4), 53-70.

Turpin, N., Dupraz, P., Thenail, C., Joannon, A., Baudry, J., Herviou, S. and Verburg, P. 2009. Shaping the landscape: Agricultural policies and local biodiversity schemes. Land Use Policy 26(2), 273283.

Tveit, M., Ode, A. and Fry, G. 2006. Key concepts in a framework for analysing visual landscape character. Landscape Research 31(3), 229-255.

Vanslembrouck, I. and Huylenbroeck, G. Van 2005. Landscape Amenities. Economic Assessment of Agricultural Landscapes. Springer, The Netherlands.

Wascher, D.M. (Ed.) 2000. Agri-environmental indicators for sustainable agriculture in Europe. European Centre for Nature Conservation, Tilburg, the Netherlands.

Wascher, D.M. 2005. The Role of Natural Vegetation Data for European Landscape Mapping and Assessment. In: Bohn, U., Hettwer, C. and Gollub, G. (Eds.) Application and Analysis of the Map of the Natural Vegetation of Europe. Bundesamt f. Naturschutz, Bonn Germany, 81-112. 
1 Wascher, D.M. and Pedroli, B. 2008. Blueprint for Euroscape 2020 - Reframing the Future of the European Landscape. JRC-ECNC Seminar: Policy Visions and Research Support. Stresa, Italy, May $3 \quad 23^{\text {rd }}-24^{\text {th }} 2008$.

4 Wood, S. A., Guerry, A. D. , Silver, J. M. and Lacayo, J. M. 2013. Using social media to quantify nature5 based tourism and recreation. Scientific Reports 3(2976).

6 Yrjölä, T. and Kola, v. 2004. Consumer Preferences Regarding MultifunctionalAgriculture.

$7 \quad$ International Food and Agribusiness Management Review 7(1), 78-90.

8 Zanten, B. T. van, Verburg, P. H., Koetse, M. J. and Beukering, P. J. H. van 2014. Preferences for 9 European agrarian landscapes: A meta-analysis of case studies. Landscape and Urban Planning $10 \quad 132(0), 89-101$.

\footnotetext{
'Nomenclature d'Unités Territoriales Statistiques (NUTS). The NUTS2 divisions correspond to the largest subnational statistical divisions, such as states, planning regions and provinces etc.

ii Local Administrative Units (LAU). LAU2 is an administrative division below NUTS2 corresponding to municipalities or electoral districts, for example Wards in the UK.
} 